\title{
THE RED-HEADED WOODPECKER IN SASKATCHEWAN, ITS STATUS AND DISTRIBUTION
}

\author{
by Rosalind Taylor, Moose Jaw
}

The Red-headed Woodpecker is a strikingly handsome bird which is widely distributed over North America from southern Canada to the Gulf states. It has been given the nickname "Red-head" in many localities because of its all red head. This feature, along with the large white wing patches and white rump, which are plainly seen in flight, makes the adult bird easy to identify. Juveniles are "duskyheaded" and often have streaked breasts (not white), so are difficult to identify except in flight, when they show the white wing patches as in the adult. Because the plumage of the juveniles is so different, naturalists in colonial days thought them a separate species (Wetmore, et al, 1964: 89). Among the woodpeckers, the Red-head is the noisiest member of the family, with an extensive repertory of harsh-sounding, shrill calls, some sounding like a loud "queer" or "queooh" (Peterson, 1961:184). The Red-headed Woodpecker is found in a variety of habitats from open farm country where there are scattered trees, to orchards and "populous towns" where they may be found nesting in telephone poles. They also nest in old dead trees, stumps and fence posts. Often a fence post or telephone pole is also used as a "look-out station." From this vantage point they dart out, flycatcher fashion, to catch a fly or other flying insect, pursue it for some distance and after catching it, return to the post or pole to await the next victim.

In Canada, the Red-headed Woodpecker (Melanerpes erythrocephalus) is found in the southern portion of the provinces from Nova Scotia to the Rockies. There are two geographic races or subspecies: the eastern race, $M$. e. erythrocephalus (Linnaeus), is somewhat smaller than the western race, $M$. e. caurinus Brodkorb ('Taver- ner, $1945: 281$; A.O.U., $1957: 318)$. According to the A.O.U. (1957), the eastern race breeds from "southern Ontario, New York, and southern New Hampshire ... south to central Texas, the Gulf coast, and Florida ...., west to Minnesota (except western portion), eastern Nebraska, eastern Kansas, and eastern Oklahoma...."The western race is supposed to breed from "southern Saskatchewan, southern Manitoba, and western Ontario south through central Montana, eastern Wyoming, and eastern Colorado to northern New Mexico and northwestern Texas, east to western Minnesota, central South Dakota, central Nebraska, central Kansas, and central Oklahoma." Throughout the northern part of its range it is a migratory species. This may be due in part to the fact that the favorite food of this bird is nuts. They also enjoy flying insects, ants, corn, berries and fruits. Bent (1939: 207 ) says that the bird's movements "seem to depend almost entirely on the abundance or scarcity of its winter food supply."

Records of the Red-headed Woodpecker in Saskatchewan go back to the latter part of the 19th century. According to Manley Callin, his father, "who knew this bird in Ontario and came to the Percival district in the early 1880's", observed it in that district "a few times" from the 1880's to the 1920's (pers. corres., October $30,1961)$. Following these early recollections without definite dates, the earliest published record I found was an apparent nesting record for June 15, 1892 at Moose Jaw: "Red-headed Woodpecker nesting on bits of decayed wood in a post." This is reported in Walter Raine's Bird-nesting in North-West Canada (1892:112). In the years since then, more than 60 observations of Red-headed Wood- 


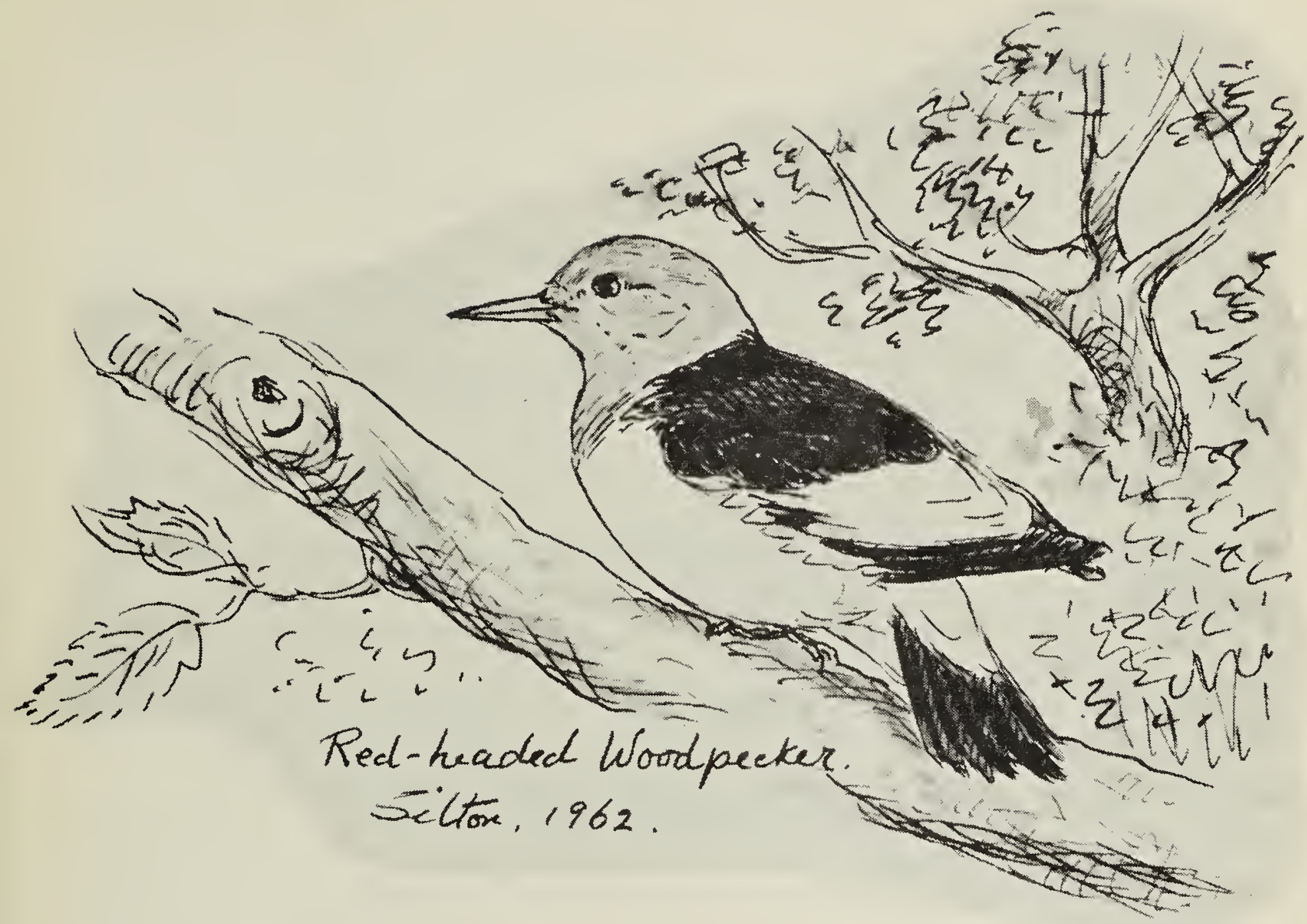

Sketch by Robert D. Symons

peckers have been recorded in Saskatchewan (see Table 1). These records were obtained through correspondence over the past few years with quite a few persons and through examination of all sources available to me. A few records which didn't seem complete enough have been omitted. One such record is that of Dr. L. G. Saunders, recently retired from the University of Saskatchewan, who reported seeing one at the University in Saskatoon in the early summer about 20 years ago. Unfortunately, he did not record the event or date and he himself wrote that this was not a "proper record" (pers. corres., January 11, 1962).

In Saskatchewan, early observers such as George Lang and L. B. Potter simply labelled this species "rare". H. Hedley Mitchell (1924) considered it an "uncommon visitant south in the lower transition zone." Among later writers, Margaret Belcher (1961:46) classified it as an "occasional visitant" in the Regina area; Manley Callin referred to it as a "very rare summer visitant" in the Qu'Appelle Valley (pers. corres., 1961) ; Stuart Houston (1949:231) considered it a "rare straggler" in the Yorkton district; and Maurice Street described it as a "rare summer straggler" in the Nipawin area (Houston and Street, 1959: 114-115). Thus, its occurrence has been noted northward to within the fringe of the Boreal Forest. It should be borne in mind that the southern edge of the Boreal Forest in this region has been greatly altered by logging and agriculture; hence these latter records are not truly within the coniferous forest (see Fig. 1). Most records, however, are from the lower transition zone as correctly judged by Mitchell (op. cit.).

John and James Macoun in their Catalogue of Canadian Birds (1909: $344)$ list five records in this province before the turn of the century. Two of these are breeding records, one in June 1894: "a pair was found breeding on the east end of the Cypress Hills"; and the other, June 1895: "observed breeding at 
TABLE I - Chronological record of the occurrence of the Red-headed Woodpecker in Saskatchewan - 1892-1964.

1892, June 15 Moose Jaw "nesting"

1894, June

1894

1895, May

1895, May

1895, June

1903, May 24

1904, Sept. 24

1905, June 9

1906, June 12,13

1906, July 19

1908, May 27

1908, June 3,4

1909, June 14

1918, Oct. 12

1920, April 30

1921, June 5

1921, June 11

1924, June 22

1927, April 2 1927, June 24

late 1920 's

1932, June 5

1933, May 16

1933, July 7

1936, May 24
Cypress Hills (east end)

$$
\text { "breeding" }
$$

Crane Lake (1)

old Wives Creek

Wood Mountain Post

"Stone Pile" on White Mud River "breeding"

Indian Head (1) George Lang

Indian Head (1) George Lang

Skull Creek (1)

C. S. Day

\section{B. Potter}

Bigstick timber (1) collected by Dwight, Cypress Hills region

Indian Head (1) George Lang

\section{East End (1) L. B. Potter}

East End (1) L. B. Potter

Lake Johnstone $=$ Old Wives Lake (1), Dr. R. M. Anderson

Eastend (1) taken by L. B. Potter

Cypress Lake (n. side) (1) Taverner

Cypress Lake (1) taken by H. M. Laing

Eastend (1) taken by L. B. Potter

Skull Creek (1) Steve Mann

Percival (Callin farm) (1) J. Elmer Callin

Torch River (1) farm of C. Stuart Francis

Near Davidson (1) W. E. C. Todd and G. M. Sutton

$9 \mathrm{mi}$. south of Prince Albert (1) Elmer Frox

Skull Creek (1) Steve Mann

Regina (1) specimen taken by N. Albulet
Raine (1892:112)

Macoun \& Macoun (1909:344)

Macoun \& Macoun (1909:344)

Macoun \& Macoun (1909:344)

Macoun \& Macoun (1909:344)

Macoun \& Macoun (1909:344)

Annual Report Sask. Dept.

Agric., 1903, p. 204

Annual Report Sask. Dept.

Agric., 1904, p. 176

Macoun \& Macoun (1909:344)

Annual Report Sask. Dept. Agric., 1906, p. 137

Godfrey (1950:45)

Annual Report Sask. Dept. Agric., 1908

Annual Report Sask. Dept. Agric., 1908

Annual Report Sask. Dept. Agric., 1909

Pers. corres., Earl Godfrey

April 2, 1962

Godfrey (1950:45)

Godfrey (1950:45)

Godfrey (1950:45)

Godfrey (1950:45)

Pers. corres., Nov. 23, 1961

Pers. corres., Manley Callin, Oct. 30, 1961

Houston \& Street (1959:115)

Todd $(1947: 406)$

Houston \& Street (1959:114)

Pers. corres., Nov. 23, 1961

Belcher (1961:46) 
1936, June 2 Silton (1) specimen taken by W. F. Van Moorlehem

1936, June 7

8 miles south of Prince Albert (1) Elmer Fox

1936, June (10?) Red Deer Hill (1) cousin of Elmer Fox

1936, June 1937, May 1930's, spring

1940, June 1

1944, spring 1946, June 4 1946, July 6

1948, June 25

1949, June 25

1949, June 28

1950 , June 1951, June 1956, spring 1956, May 22-25 1956, summer

1957, summer

1957, June 9 1958 , summer

1959, May 5

1959, Sept.

1960, June 11

1961, May 28

1961, June 5 1961, June 5

1961, June 15

1962, June 2

1962, June 5
Yorkton (1) Mrs. I. M. Priestly

Tullis (2) J. Frank Roy

Moose Jaw (farm $6 \mathrm{mi}$. west) (1) G. F. Ledingham

Oakshela (1) John F. Nelson

Indian Head (1) Bill Wilson Skull Creek (1) Steve Mann

Sheho (1) William Niven and his brother

Cypress Hills (1) Earl Godfrey

Saltcoats, 12 mi. south (1) Dave Baines

Saltcoats (1) Frank Baines

Tisdale (1) K. E. Baines

Tisdale (1) K. E. Baines

Kindersley area (1) Glen Fox

Skull Creek (1) Steve Mann

Torch River (1) C. Stuart Francis farm

Torch River (1) C. Stuart Francis farm

Skull Creek (1) Steve Mann

Regina (1) Fred Bard and F. W. Lahrman

Estevan (1) Darrel Carlson

Moose Jaw (1) Mr. and Mrs. C. V. Stokins

Regina (1) members of Regina Nat. Hist. Soc.

Regina (1) G. F. Ledingham

Skull Creek (1) Steve Mann

Vanscoy (1) J. B. Gollop (6 mi. east and $1 \mathrm{mi}$. north)

Eston ferry (1) Alex Dzubin and $R$. A. Lamont

Indian Head (1) members of Regina Nat. Hist. Soc.

(a mile south of Forestry Station) G. F. Ledingham

(Univ. Campus)
Regina (1) R. W. Nero and
Pers. corres., Fred Bard

Nov. 27, 1961

Houston \& Street $(1959: 114)$

Houston \& Street $(1959: 114)$

Blue Jay, II (4) :33

Roy (1964)

Pers. corres., March 6, 1962

Pers. corres., Manley Callin

Oct. 30, 1961

Blue Jay, III (1) :9

Pers. corres., Nov. 23, 1961

Pers. corres., Nov. 6, 1963

Blue Jay, IV (4) :42

Godfrey (1950:45)

Blue Jay, VIII (1) :7

Baines (1950)

Baines (1952)

Baines (1952)

Pers. corres., Feb. 4, 1963

Blue Jay, XIV (3), Cover 3

Houston \& Street (1959:115)

Houston \& Street $(1959: 115)$

Pers. corres., Nov. 23, 1961

Pers. corres., Fred Bard

Nov. 27, 1961

Pers. corres., Ross Lein

Nov. 23, 1961

Belcher (1961:46)

Belcher (1961:46), also pers. corres., G. F. L., Mar. 6, 1962 Pers. corres., Nov. 23, 1961 Pers. corres., Oct. 27, 1961

Pers. corres., J. B. Gollop, Oct. 27, 1961

Pers. corres., R. W. Nero, March 20, 1963

Pers. corres., R. W. Nero, March 20, 1963 
1962, June 6

1962, June 23

1962, June 27

1963, June 3

1963, June 20

1963, July

1964, May 22

to June 5

1964, June 12

1964, June 24

(or 25)
Kindersley area (1) Glen Fox

Regina area (2 mi. N.W.

Pinkie) (1) R. W. Nero and family

Pelican Point, Last Mountain Lake (1) R. D. Symons

Skull Creek (1) Steve Mann

Cypress Hills (centre block)

(1) R. V. Folker and Bob Caldwell

Moose Jaw (farm $6 \mathrm{mi} \mathrm{W.)}$

(2) (1 first observed by

Frank Brazier July 7)

(2 observed by Mrs. F. B. Taylor and Mrs. Cy Knight July 23 to end of July)

Regina, Sask. Museum of Nat. History grounds (2) Frank Brazier, R. W. Nero, Fred Lahrman, Ruth Tempel. (photographed by Lahrman, pers. corres., Dec. 9, 1965)

Aud. Field Notes 18 (4) :463;

Aud. Field Notes, 18 (5):517 tery) (1), Mrs. Cy Knight

Val Marie (17 mi. S.E.) Ruth Chandler (5) :517

Pers. corres., Feb. 4, 1963

Pers. corres., R. W. Nero, June 23, 1962

Blue Jay, XX (4):146

Pers. corres.

Folker (1963)

Taylor (1963)

Pers. corres., April, 1966
'Stone Pile' on the White Mud River, Sask." In order to locate these places on the map, I delved a bit into the history of that corner of the province. I had difficulty in finding Stone Pile and White Mud River, but I found the answer in Wallace Stegner's Wolf Willow which has an excellent map of the southwestern part of the province. In his first chapter he explains how the name of the White Mud River was changed to the Frenchman River in order to conform with American maps.

These are significant records, since these and the Moose Jaw record (which is open to some uncertainty because of Raine's dubious reputation) are the only breeding records for the province. Both of the Macoun records are from the extreme southwestern portion of the province, a region which has yielded 22 individual records or about one-third of the total records for the province. Of the 30 places in Saskatchewan in which Redheaded Woodpeckers have been ob- served, seven are from this corner of the province: Cypress Hills and $\mathrm{Cy}$ press Lake (six observations), Crane Lake (one), Eastend (five), Val Marie (one), "Stone Pile" (one), and Skull Creek (eight). The southwestern area may provide a more favorable habitat for this species than elsewhere in the province, but probably the abundance of records here results from this area being on the northern fringe of its breeding range in Montana.

It is of interest to note that all the records in this century have been single birds, with three exceptions, the two at Tullis (for one day) in 1937, the two in Moose Jaw in 1963, and the two in Regina in 1964. In the early years there were few observers in the field and this may account for the few records. From 1895 to 1903 there is a gap of eight years with no records, and another interval of nine years between 1909, with only one observation, and 1918 with just one. Starting with the decade of the 1920's 
TABLE 2-Saskatchewan places in which the Red-headed Woodpecker has been observed, with the number of observations and years. No.

Place Observed Dates

Crane Lake ... 11894

Cypress Hills

\& Lake ...... $7 \quad 1894$ (2) - 1906 -

'21 (2) - '48 - '63

Davidson ....... 11932

Eastend \& Wh. Mud R.

$5 \quad 1906$ - '08 - '09 - '20

-24
1

Eston ferry .... 1

Indian Head .. 5 1903-'04-'08-'44

Johnstone

-'62

Lake (Old

Wives) ....... 11918

Kindersley ..... 2 1956 -'62

Moose Jaw ..... $6 \quad 1892-1930$ 's - '59 $-63(2)-' 64$

Old Wives'

Creek ......... 11895

Oakshela ....... 11940

Pelican Point

(Last Mt.

Lake) ….... 11962

Percival ........ 1+ 1880-'20 (several) $-27(1)$

Prince Albert. 2 1933-'36

Red Deer Hill 11936

Regina ......... 81936 - '58 -'60 - '61

Saltcoats ...... $2 \quad 1949$

Saskatoon ..... 11942 (date

Sheho …........ 11946 approx.)

Skull Creek ... 8 1905-'27-'33-'46

Silton ............ 111936

Stone Pile ..... $2 \quad 1895$

Tisdale .......... $2 \quad 1950-' 51$

Torch River... 31920 - '56 - '57

Tullis .......... $2 \quad 1937$

Val Marie ..... 11964

Vanscoy ......... 11961

Wood Moun-

tain Post ... 11895

Yorkton ........ 11936

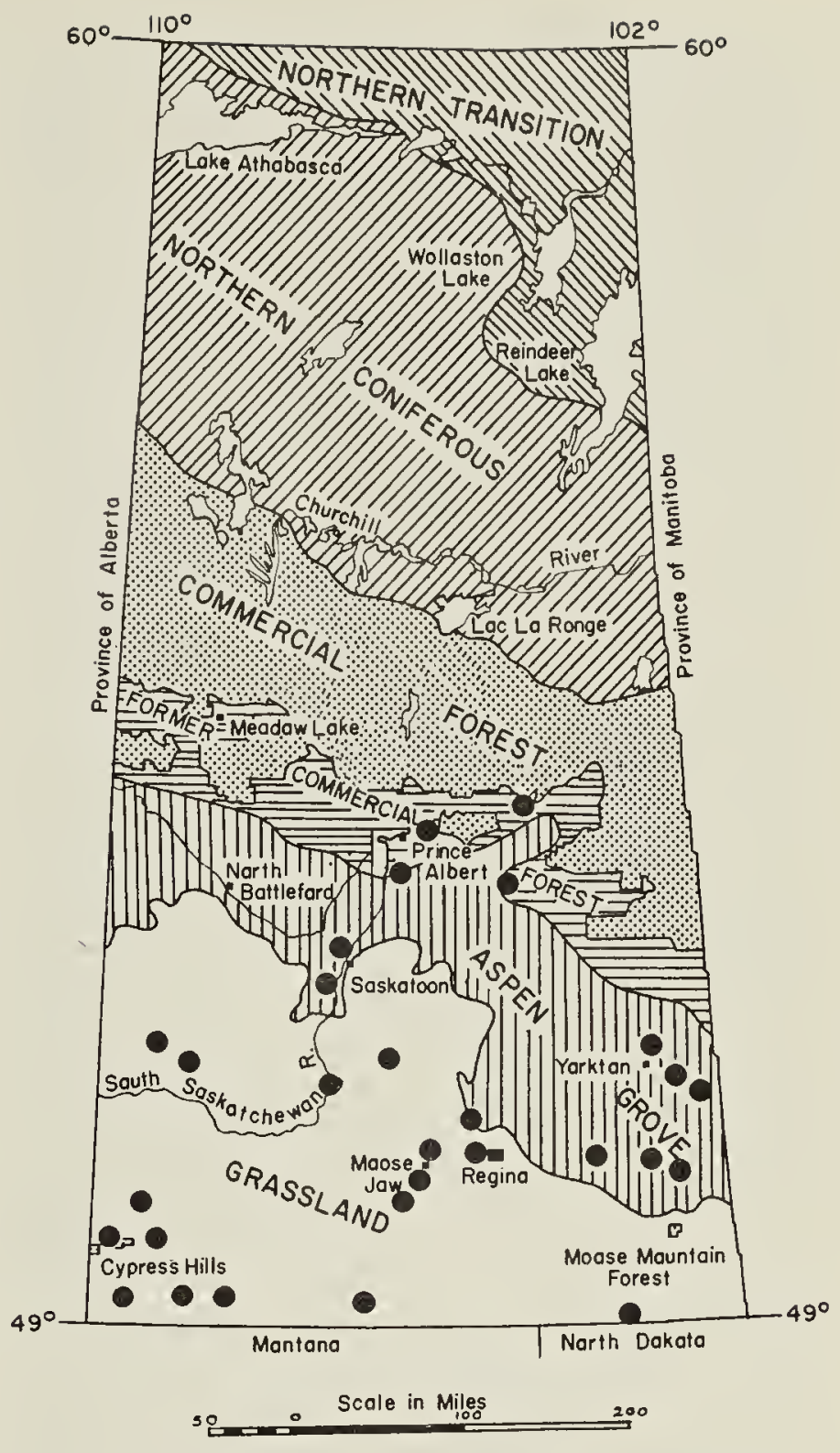

Figure 1 - Approximate location of Red-headed Woodpecker records shown by black dots; note four records close to or within former commercial forest belt. Map redrawn from Forest resources in Saskatche. wan, Cons. Bull. No. 8, Dept. Natural Resources, Regina.

TABLE 3 - Red-headed Woodpecker observations according to months:

April

2 observations

May

June

July

August

Sept.

Oct.

12 observations

39 observations

4 observations

None

2 observations

1 observation

Indefinite $\quad 9$ spring or summer 
(seven observations), the number of observations has had a general tendency to increase each decade (see Tauble 4). The 1930's yielded 11 observations; the 1940 's the same number as the 1920's. In the 1950's there were 10 observations, and in the first five years of the present decade 18 observations were obtained. These increases are no doubt due in part to the greater number of observers. However, some years seem to be peak years, e.g., 1963, which suggests a possible correlation between occurrence and some weather factors such as drought. In 1963, Herb Copland (Winnipeg) commented that he had seen "many more Red-headed Woodpeckers than in past years." David Hatch reported seeing one on June 16 at Oak Lake, Manitoba "where the species is a rarity" (Audubon Field Notes, Oct., 1963). And this is the year we abserved two individuals near Moose Jaw during the month of July. The same issue of Audubon Field Notes reported increases in the Middle-western Prairie Region ( $p$. 464), the Southern Great Plains Region (p.468) and a "heartening upswing" in Mahoning County, Ohio (p.460). It will be interesting to follow up this decade to see whether this increase continues.

In this article I have included only a few records of neighboring provinces, wishing to concentrate mainly on the Saskatchewan records. I understand that a similar survey for this species is now being made in Manitoba by Herb Copland, a member of the Natural History Society of Manitoba. The Manitoba records were of interest to me principally from the standpoint of breeding, for Manitoba seems to be the farthest point west in Canada that the Red-headed Woodpecker regularly breeds. Although the Manitoba Museum has no official breeding records (pers. corres., R. W. Sutton, Dec. 4, 1961), John and James Macoun in their Catalogue of Canadian Birds (1909:344) stated that it is a "species which is rapidly increasing in numbers in the heavier wooded districts of Manitoba, having become quite a regular breeding species about

TABLE 4-Number of observations per year and decade:

1892

1894

1895

1903

1904

1905

1906

1908

1909

1918

1920

1921

1924

1927

1932

1933

1936

1937

1930's

1940

1944

1946

1948

1949

1950

1951

1956

1957

1958

1959

1960

1961

1962

1963

1964
1 observation

2 observations

3 observations

8 years - no records

1 observation

1 observation

1 observation

2 observations

2 observations

1 observation

9 years - no records

1 observation

1 observation

2 observations

1 observation

3 observations

total observations -7

1 observation

2 observations

5 observations

2 observations

1 observation

total observations -11

1 observation

1 observation

2 observations

1 observation

2 observations

total observations - 7

1 observation

1 observation

3 observations

2 observations

1 abservation

2 observations

total observations -10

1 observation

4 observations

5 observations

4 abservations

4 observations

Total observations -18

in 5 years of this decade. 
Portage la Prairie along the Assiniboine River east." Several members of the Natural History Society of Manitoba have sent me recent records. Dr. L. B. Smith has among his records one of a juvenile seen near Carmen, Manitoba (Sept. 10, 1961), also a record of one adult and one juvenile seen together at St. Agathe, Man., Aug. 24, 1962 which "may indicate breeding there" (pers. corres., Aug. 10, 1963). Martin McNicholl has an Aug. 23, 1963 record of one young and two adults observed at Loni Beach, Man. (pers. corres., Oct. 16, 1963) and Herb Copland has among his 1963 records several of young and adults which gives further evidence of their breeding in the province: Aug. 3, Lockport, Man.; Aug. 7, Hawthorne Ave., N. Kildonan \& Rossmere Ave., East Kildonan; Aug. 17, Dunnottar Village (Whytewold) two adults with four young and same date, two adults and four young at Wildwood Park, Ft. Garry, Man. (pers. corres., Sept. $6,1963)$. Audubon Field Notes $(19,5$ : 556) states that "in Manitoba they breed along the Red River valley" (1965).

In Alberta the Red-headed Woodpecker is classified by the A.O.U. (1957) as "casual". Salt and Wilk in their Birds of Alberta (1958:254) call the bird an "erratic wanderer" that has been "reliably recorded from Waterton Lake, Formost, Medicine Hat, Calgary, Rosebud, Viking and Elk Island Park." A. L. Rand in his Birds of Southern Alberta (1948:37) records a bird taken at Medicine Hat as early as May 24, 1894, one recorded in Waterton Lakes Park June 2, 1922, and three in the same locality July 17 , 1922. Sam Alberts reported seeing one in the summer of 1940 or 1941 , nine miles northeast of Brooks. He commented in his letter (pers. corres., November 28, 1963) that he had no doubt about the identification of the bird, since he had moved to Alberta from Nebraska where the bird was very common and that this was the only Red-headed Woodpecker he had seen since he moved into the area. Dr. M. T. Myres of the Department of Biology of the University of Alberta at Calgary (pers. corres., April 1, $1966)$ states that they have no breeding records for southern Alberta and that the species is "an accidental vagrant" in this region. A recent observation of one Red-headed Woodpecker seen by Murray Christman (July 23, 1965) in the Silver Creek area near Water Valley, Alberta, was reported in Bulletin No. 42 of the Calgary Bird Club (November 22, 1965 , p. 4; M. T. Myres, editor); M. Christman (pers. corres., May 3, 1966).

Recently British Columbia reported its first authentic record of a Redheaded Woodpecker, a single bird "obtained in mid-July (1965) near Lavington in the southeastern portion of the province" (Audubon Field Notes, Vol. 19, No. 5, p. 520). However, Bent (1939) said it was reported in B.C., and Macoun and Macoun $(1909: 344)$ reported "a pair seen at Pass Creek, near Robson, Columbia River, B.C., June 25, 1890."

I should appreciate it if birders throughout the province would send me any observations they have or may obtain. June is an excellent month to watch for Red-headed Woodpeckers, for more than half of the total observations have been made in this month (see Table 3).

\section{Acknowledgements}

The initial inspiration for this report came from my participation in an adult education course on the birds of Saskatchewan given in the fall of 1961 by Dr. R. W. Nero. The students in this class were asked to consider changes in distribution of bird species in Saskatchewan that seemed to show some response to drought, such as the Lark Bunting. We were encouraged to prepare a report on one of these species, making a survey of the literature for this purpose. I chose the Redheaded Woodpecker, and have been at work since that time collecting the records included in this report. My thanks are due to Dr. Nero, who not only suggested the study, but has since helped to direct its progress. 


\section{LITERATURE CITED}

American Ornithologists' Union. 1957. Checklist of North American birds. Fifth Edition.

Baines, Frank. 1950. Birds at Saltcoats. Blue Jay, 8 (1):7.

Baines, K. E. 1952. Visitors at Tisdale. Blue Jay, 10 (1):12.

Belcher, Margaret. 1961. Birds of Regina, Sask. Nat. Hist. Soc. Special Pub. No. 3.

Belcher, Margaret, and Maureen Rever. 1962. Getting to know our less common birds. Blue Jay, 20 (4) :146.

Bent, A. C. 1939. Life histories of North American woodpeckers. U.S. Nat. Museum Bull. 174 .

Folker, R. V. 1963. Red-headed Woodpecker in Cypress Hills. Blue Jay, 21 (3):93.

Godfrey, W. Earl. 1950. Birds of the Cypress Hills and Flotten Lake Regions, Sask. Natl. Mus., Can., Bulletin No. 120.

Houston, C. Stuart. 1949. The birds of the Yorkton district, Sask. Can. Field-Naturalist, $63(6): 215-241$.

Houston, C. Stuart, and Maurice G. Street. 1959. The birds of the Sask. River, Carlton to Cumberland. Sask. Nat. Hist. Soc. Special Pub. No. 2.
Macoun, John, and James M. Macoun. 1909. Catalogue of Canadian birds. Dept. of MinesGeological Survey Br.

Mitchell, H. Hedley. 1924. Catalogue of the birds of Sask. Can. Field-Nat. Special Number, Vol. $38(6): 101-118$.

Peterson, R. T. 1961. A field guide to western birds. Houghton Mifflin Co., Boston.

Raine, Walter. 1892. Bird-nesting in NorthWest Canada. Hunter, Rose \& Co., Toronto.

Rand, A. L. 1948. Birds of southern Alberta. National Museum of Canada, Bull. No. 111.

Roy, J. F. 1964. An introduction to the birds of the Elbow. Sask. Nat. Hist. Soc., Regina. Mimeo., 33p.

Salt, W. Ray, and A. L. Wilk, 1958. The Birds of Alberta. Queen's Printer, Edmonton.

Stegner, Wallace. 1962. Wolf Willow. The Viking Press, N.Y.

Taverner, P. A. 1945. Birds of Canada. Natl. Mus. Can.

Taylor, Rosalind. 1963. Unusual Red-headed Woodpecker record in Moose Jaw area. Blue Jay, 21 (4) :140.

Todd, W. E. Clyde. 1947. Notes on the birds of southern Sask.; Annals of the Carnegie Museum, Vol. 30, Art. 22.

Wetmore, Alexander (and other eminent ornithologists). 1964. Song and Garden Birds of North America. Natl. Geog. Soc., Wash., D.C.

\section{SASKATCHEWAN LONG-EARED OWL RECOVERED IN MEXICO}

\section{by C. Stuart Houston, Saskatoon}

On January 26, 1965, Mr. Glen Peterson of Orland, California, was in the village of Mitla, state of Oaxaca, Mexico, when he was approached by an elderly Mexican who took a small packet from his pocket. $\mathrm{He}$ opened it and took out the foot of a bird, the shank of which was covered with fine tan feathers and the toes of which had talons almost threequarters of an inch long. It carried an aluminum band \#526-22635. The old man reported that a boy had found the bird dead and hanging in a tree nearly five years previously in the mountains about three days walk to the south, near Ejutla, Oaxaca.

The bird was a Longeared $\mathrm{Owl}$ that I had banded on June 15,1960 , on the farm of Len Bruce, seven miles east and five miles north of ialtcoats, Saskatchewan. This species of owl is migratory, unlike its larger relative, the Great Horned Owl. Ejutla is 250 miles south of Mexico City, and about 2,500 miles south of Saltcoats.

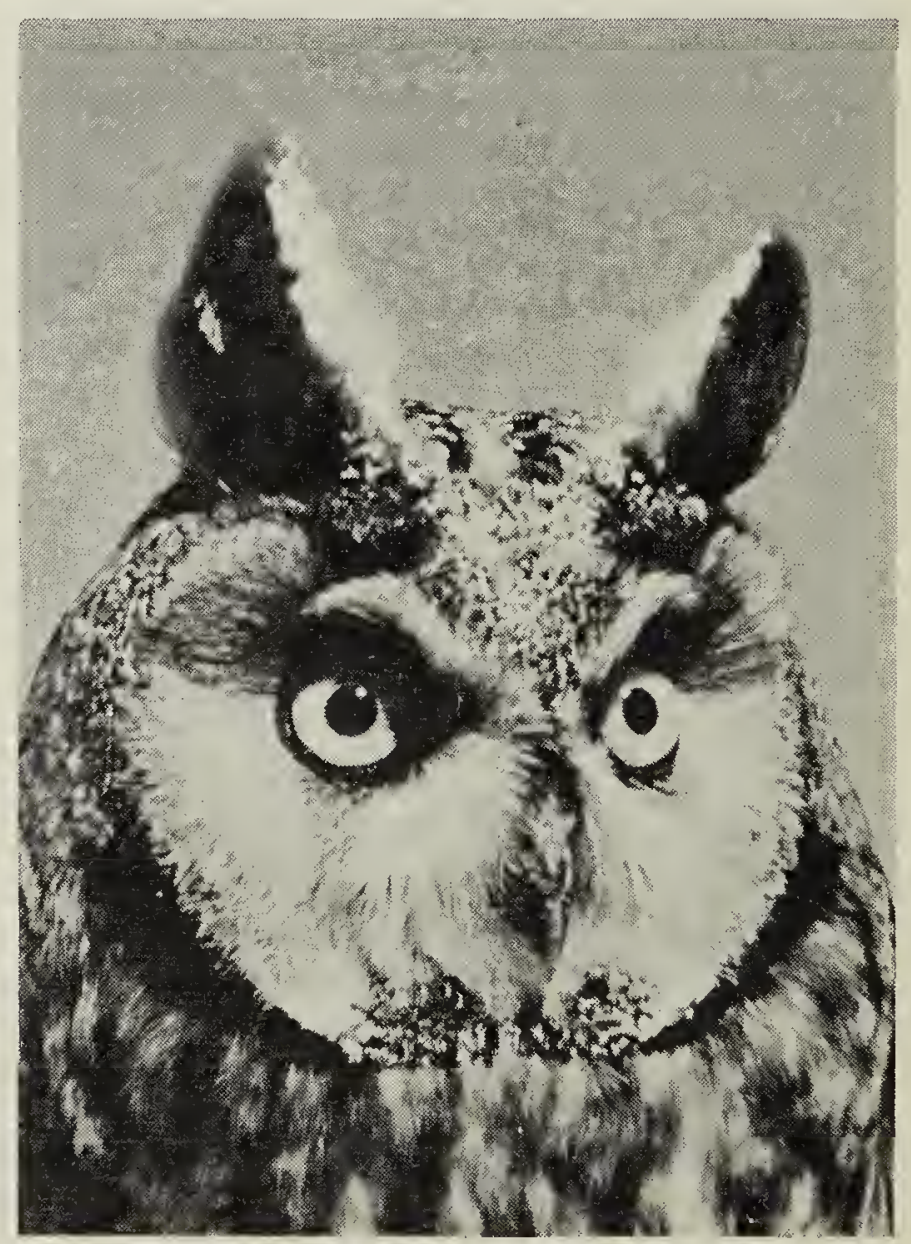

Photo by Stuart Houston

Long-eared Owl, October 20, 1965 